\title{
Na obrzeżach ludzkiego świata. Zwierzęta w poezji Grzegorza Wróblewskiego
}

Justyna Kasperek

TEKSTY DRUGIE 2021, NR 3, S. 305-316

DOI: $10.18318 /$ td.2021.3.20 | ORCID: 0000-0002-2963-4045

$\mathbf{N}^{2}$

a przestrzeni wieków powstał zarówno w mowie, jak i w literaturze cały wachlarz metafor, w którym poszczególne zwierzęta oznaczają ludzkie wartości, normy czy obyczaje. Kreacje te posłużyły do utworzenia "systemu podpierającego ludzkie projekcje siebie i aspiracje moralne"1. Zazwyczaj wykorzystywano je do zilustrowania cech człowieka oraz jego sposobu bycia. Tym samym pozostawał on $\mathrm{w}$ centrum zainteresowania czy też „opowieści”. Jego perspektywa dominowała w tworzeniu literackich odniesień (zawierających również pewien element rozumienia) do rzeczywistości.

W poezji Grzegorza Wróblewskiego „czytanie” kreacji zwierzęcych według utrwalonego $\mathrm{w}$ tradycji słownika bestiarium jest dość trudne (jeśli w ogóle możliwe). Wydaje się, że w jego utworach „zaczęły raczej być traktowane
Justyna Kasperek

- doktorantka na Uniwersytecie im. Jana Kochanowskiego w Kielcach. Interesuje się współczesną poezją polską. Przygotowuje pracę doktorską poświęconą twórczości literackiej Grzegorza Wróblewskiego. Kontakt: katechopinid@gmail. com

1 R. Braidotti Zwierzęta, anomalie i nieorganiczni inni, http://machinamysli.org/zwierzeta-anomalie-i-nieorganiczni-inni/ (22.09.2019). Zagadnieniu posthumanizmu autorka poświęciła książkę Po człowieku (przeł. ). Bednarek, A. Kowalczyk, Wydawnicwo Naukowe PWN, Warszawa 2014). 
dosłownie, jako istoty otoczone własnymi systemami kodowania. [...] Nie stanowią funkcjonalnych części teleologicznych taksonomii ani nie są metaforami - raczej uczestniczą w etiologii sił i przyspieszają metamorfozy. Wyrażają literalne formy immanencji i stawania-się"2. Każde zwierzę zachowuje swoje cechy. Poeta nie odbiera właściwych mu reakcji, nie nadbudowuje znaczeń, by następnie odnieść je jako ilustrację do zachowania ludzi. Ich obecności przenikają się, czasem nawet zapętlają we wspólnych, niekiedy surrealistycznych relacjach.

Inna sprawa, że zwierzęta, a pośród nich również człowiek, w twórczości zamieszkałego w Kopenhadze poety przebywają w przestrzeni w znacznej mierze skonstruowanej z narracji oraz przekazów (medialnych, obyczajowych, kulturowych) kształtujących światopogląd. Za przykład takiej intuicji może posłużyć wiersz Chustka Sandry, w którym Wróblewski przywołuje losy orangutana $\mathrm{z}$ argentyńskiego ZOO.

Dość łatwo w polskich i zagranicznych mediach, głównie on line, można odnaleźć informację dotyczącą bezprecedensowego wyroku sądu Buenos Aires dotyczącego orangutana o imieniu Sandra. Zwierzę to zostało na mocy prawa uznane za "osobę" (co, jak podkreślano, nie było jednak tożsame z byciem człowiekiem). Zmiana sposobu definiowania czy też pojmowania Sandry spowodowała modyfikację stosowanych wobec niej przepisów. Dostrzeżenie w niej pewnych znamion ludzkich stało się przyczyną uznania, że dalsze jej przetrzymywanie w ogrodzie zoologicznym nie jest zgodne z prawem, i tym samym stworzyło możliwość przeniesienia jej do rezerwatu przyrody ${ }^{3}$.

Grzegorz Wróblewski w wierszu Chustka Sandry wydaje się wskazywać na etyczną dwuznaczność sytuacji orangutana. Z jednej strony na mocy postanowienia sądu zostaje zwrócona (nieznana dotąd) Sandrze wolność. Choć precyzyjniej rzecz ujmując, stworzono możliwość przeniesienia jej do rezerwatu, który w rzeczywistości, podobnie jak ogród zoologiczny, jest co prawda większą, lecz nadal ograniczoną przestrzenią. Z drugiej strony wyrok ten w jakimś sensie demaskuje zależność losu zwierzęcia od nadawanych przez człowieka sensów oraz dokonywanej z jego perspektywy interpretacji ontycznej rzeczywistości, tj., aktywności polegającej na określaniu ludzkiego

2 Zob. R. Braidotti Zwierzęta, anomalie i nieorganiczni inni.

3 Zob.m.in.https://time.com/5687210/sandra-orangutan-zoo-florida-sanctuary/; https://www. bbc.com/news/world-us-canada-49856859; https://www.tvn24.pl/wideo/magazyny/prawa-malpy,1373875.html?playlist_id=12698 (22.09.2019). 


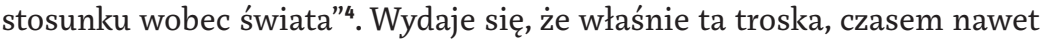
walka człowieka o lepszy byt „braci mniejszych” najwyraźniej eksponuje jego dominację pośród pozostałych istnien. Świadczy bowiem o pozostającej w jego mocy możliwości decydowania o standardzie ich życia, rozmiarze zaznawanego bólu czy nawet śmierci. Można przypuszczać, że skuteczność działalności obrońców praw zwierząt odnosi się głównie do siły używanej przez nich retoryki, która w mniejszym bądź większym zakresie wpływa na sposób ludzkiego myślenia i, co za tym idzie, postrzegania zwierząt. Co więcej, mimo przekonania homo sapiens o własnej niezachwianej pozycji dominującego pośród innych istnień, dobór stosowanych przezeń określeń może poniekąd wpłynąć na relacje człowiek-zwierzę. Określa bowiem perspektywę oglądu rzeczywistości.

Sposób zapisu Chustki Sandry łudząco przypomina zamieszczane w Internecie, „poszarpane" reklamami, krótkie wiadomości informacyjne. Ingerencja w retorykę wypowiedzi prasowej jest w wierszu Wróblewskiego ledwie zauważalna. Opowieść o losach orangutana, utrzymana w sensacyjnym tonie doniesień reporterskich, jest w utworze rozbita przez umieszczoną w nawiasie reklamę. Bohater wiersza początkowo wydaje się nieobecny, niejako pominięty „przez utwór”. Jest to jednak tylko wrażenie. Dalsza lektura coraz bardziej go odsłania spoza informacji prasowej. Zapisane, początkowo w nawiasie, pytanie: „Co zrobić ze słoniem i panterami?”, można odczytać jako sugestię jego wrażliwości wobec zwierząt. Choć może ono być również rozumiane jako komentarz do przedstawionego w utworze zdarzenia. Z czasem głos osoby mówiącej w wierszu staje się coraz bardziej donośny. Wychodzi, dosłownie, poza nawias, by wybrzmieć w zakończeniu utworu. Forma pytająca, a właściwie retoryczność oraz refreniczność tej wypowiedzi dodatkowo wzmacniają zawartą w niej treść. Wiersz kończy pytanie: „Co zrobić ze słoniem i panterami?". Umieszczenie otwartego, tj. pozbawionego odpowiedzi, pytania w klauzuli może sugerować brak holistycznego, uwzględniającego wszystkie zwierzęta sposobu ich postrzegania, jak również istnienie znacznych rozbieżności w tej kwestii. To jedna z nasuwających się intuicji, inna może nieść ze sobą nadzieję na przełom niosący znaczące zmiany w myśleniu, które w konsekwencji doprowadzą do mniej przedmiotowego postrzegania pozostałych istnień. Niemniej wszelkie zmiany dotyczą intersubiektywności, rozumianej jako rozmaite strategie poznawcze i zdolności umożliwiające

4 A.W. Nowak Oznaczanie jako władza. Pomiędzy metafizykq a teoriq i krytykq społecznq, w: Wgąszczu znaków, red. P. Orlik, Wydawnictwo Naukowe UAM, Poznań 2004, s. 84. 
człowiekowi wieloperspektywistyczny ogląd świata, sytuacji oraz postrzeganego Innego 5 .

Z dotychczasowych rozważań wynika, że poeta zbliża swoje wiersze do znanego z otaczającej rzeczywistości szumu językowego. Zawęża w ten sposób perspektywę jej poetyckiego oglądu. Można powiedzieć, że jest to jedna z cech tej twórczości sugerujących jej bliskość z poetyką Reznikoffa czy innych obiektywistów amerykańskich ${ }^{6}$. Jest w tych wierszach pewne skupienie na szczególe. Wydaje mi się, że chcąc właściwie określić wpisaną w nie rzeczywistość, można się odwołać do terminologii związanej z fotografią. To, co jest prezentowane w utworach zamieszkałego w Kopenhadze poety, to makroobraz. Jeśli bohater wierszy Wróblewskiego obserwuje przestrzeń, to często skupia uwagę na małym fragmencie krajobrazu lub sytuacji wyciętej z szeregu zdarzeń, np.: „Mięsożerny chłopiec / I mięsożerny ptak”, ,autentyczna, / przyczajona mucha”, ,wróble przyglądające się / dojrzałym słonecznikom”,,„Siedząca obok [...] sroka”, „Ptak Dodo”, „Polny konik schował się za koszykiem rozebranej / do naga Henrietty"7. Aby (roz)poznać nowy teren lub wyznaczyć punkty orientacyjne w nieznanej przestrzeni, poeta nie wizualizuje świata, ,jakby ten był widziany z powietrza, z przestworzy" ${ }^{\prime}$. Tak szeroka perspektywa była używana w poezji już od antyku. Górskie wzniesienia jako motywy literackie często pojawiały się jako symboliczne miejsca poznania (lub spotkania). Dawały gwarancję ujrzenia znacznej części krajobrazu oraz, co za tym idzie, jego poznania.

Grzegorz Wróblewski w swojej twórczości odchodzi od stosowania dalekiej perspektywy. Wydaje się, że tzw. punkt widokowy zostaje w jego utworach umieszczony na obrzeżach "krain”, rozumianych przeze mnie jako prezentacje różnych ujęć społeczno-kulturowej natury człowieka. Bohater tych wierszy obserwuje otoczenie niejako z obrzeży ludzkiego świata, ze

5 Zob. M. Rembowska-Płuciennik Poetyka intersubiektywności. Kognitywistyczna teoria narracji a proza XX wieku, Wydawnictwo Naukowe UMK, Toruń 2012.

O widocznych wpływach tego amerykańskiego poety w twórczości Grzegorza Wróblewskiego pisano już kilkakrotnie, zob. m.in. http://artpapier.com/index.php?page=artykul\&łwydanie$=372$ Erartykul=7349धłkat=17 (25.10.2019); K. Płatek Wymaz ze współczesności, "Nowe Książki" 2019 nr 6, s. 15-16; o swojej fascynacji twórczością Charlesa Reznikoffa wspomina również sam Wróblewski, w książce Miejsca styku (Convivo, Warszawa 2018).

7 Cytaty pochodzą ze zbiorów: Planety (1994), Dolina Królów (1996), Symbioza (1997), Pomieszczenia i ogrody (2005), Pan Roku, Trawy i Turkusów (2009), Dwie kobiety nad Atlantykiem (2011).

8 N. Mirzoeff/ak zobaczyć świat, przeł. Ł. Zaremba, Karakter i Muzeum Sztuki Nowoczesnej, Kraków-Warszawa 2016, s. 114. 
świadomością istnienia innych perspektyw poza antropocentryczną. Tym samym poezja ta w jakimś sensie demaskuje ludzkie myślenie, uwikłane obyczajowo-historycznie, a także stawia pytania w kwestiach aksjologicznych. Ponadto bohater poezji Grzegorza Wróblewskiego uważnie przygląda się światu, który wydaje się zdominowany przez człowieka zaznaczającego swą obecność w przyrodzie. Obserwuje jego działania oraz tworzone wokół nich interpretacje, które wydają się kwestionować funkcjonujący w naukach biologicznych termin określający go jako homo sapiens - człowieka rozumnego. A może nie wszystko jest tak, jak się wydaje...? Może sposób definiowania siebie oraz innych bytów ukazuje (a następnie utrwala) niewłaściwą perspektywę oglądu rzeczywistości? Odnosi się wrażenie, że w wierszach, w których istotnym elementem są kreacje zwierzęce, poeta poddaje utrwalone w języku antropocentryczne konstrukcje myślowe właśnie takiej rewizji.

Jako ilustracja takiego nastawienia może posłużyć wiersz Makamba, odnoszący się do wciąż żywego w krajach afrykańskich przekonania o mocy, której źródłem ma być (choćby fragment) ciała albinosa. W tekście realnie istniejąca postać zostaje zestawiona z magicznym zwierzęciem, jakim jest jednorożec. Wspólną cechą ich obu jest, według narracji przytaczanych przez bohatera wiersza, dysponowanie niezwykłą, magiczną mocą. Właściwie utwór ten można potraktować jako odwrócenie historii użytej w Chustce Sandry. Tym, co łączy oba wiersze, jest wskazanie na potęgę języka, który może nobilitować zwierzę do myślenia o nim jako „osobie” lub zdegradować postrzeganie człowieka do patologicznego sposobu wyobrażania go przez zbiorowość jako „nie-człowieka”. „Język jest tworem określonego czasu, odpowiada różnym grupom interesów, utrwala i przechowuje różne formy władzy i panowania. To, co dla jednych stanowiło akt nazwania dokonany ze względu na użyteczność rzeczy i ludzi dla nich samych, innym przysparza cierpień jako forma zniewolenia". Nie ulega wątpliwości, że jest to narzędzie używane do budowania podziałów i gradacji. Wpływa również na kształtowanie postawy lub jej zmiany wobec innych obecności, modyfikację sposobu ich definiowania. To również w mowie, w strategicznych opowieściach są budowane, z czasem w nim utrwalane, konstrukcje myślowe, za pomocą których definiowana jest rzeczywistość.

Poetyckie (ludzkie) „ja” Grzegorza Wróblewskiego zazwyczaj nie zostaje umieszczone w centrum wielu jego wierszy, lecz pozostaje na dalszym planie. Wydaje się, że jest ono równorzędne całej reszcie innych obecności. Postać poetycka uważnie obserwuje otaczającą ją przestrzeń, zwracając szczególną

9 A.W. Nowak Oznaczanie jako władza, s. 86. 
uwagę na przebywające tam zwierzęta., Zdechły wróbel na przystanku / przy Oxford Street [...]", ciało potężnej morskiej mewy na plaży,„Akwarium pełne zdechłych ślimaków", gołębie pukające w szyby ${ }^{10}$ to obrazy budujące napięcie tych utworów, w pewien sposób naruszające również przyjmowaną za oczywistą hierarchię gatunkową, która nie tylko stawia na szczycie drabiny ewolucyjnej człowieka, lecz także w jakimś stopniu mianuje go opiekunem (jeśli nie władcą) pozostałych istnień. Wróblewski w swoich wierszach zdaje się nieznacznie naigrawać z tej samozwańczej pozycji. W wierszu Konie 2013 $3^{11}$ czytamy: „Wszechświat jest do naszej / dyspozycji. Gaśniemy o wiele szybciej niż słońce". Zestawienie treści zawartych w obu zdaniach sugeruje pewne zachwianie myśleniem o potędze, jaka wydaje się udziałem ludzkości. Poeta konfrontuje dwa różne (może nawet wykluczające się wzajemnie) poglądy. Zderzając je, buduje pewnego rodzaju komizm, nie by rozśmieszyć, lecz by zdekonspirować jedno z największych ludzkich narzędzi władzy, jakim jest mowa (jako retoryka), kształtująca rozumienie czy interpretację otaczającej przestrzeni. Jak dowodzą wiersze Chustka Sandry oraz Makamba, istotny czynnik wywołujący i w jakimś sensie napędzający ludzkie działania.

Różnorodne kreacje zwierzęcych bohaterów, takich jak psy, koty, muchy, pająki, gołębie, wrony, kałamarnice, są obecne w niemal każdej książce Grzegorza Wróblewskiego. Jest to jeden z częstszych motywów w jego poezji, zarówno wczesnej, jak i tej publikowanej ostatnio ${ }^{12}$. W wierszu Metamorfoza, pochodzącym z jego debiutanckiej książki poetyckiej zatytułowanej Ciamkowatość życia, bohater relacjonuje spotkanie z gołębiem pocztowym oraz mówi o konsekwencjach tego zdarzenia. Ukazana sytuacja sugeruje metaforyczne odniesienie do genezy działań, przekonań czy budowania relacji. Można w tym momencie pokusić się o próbę analizy tego utworu przez pryzmat psychologii społecznej i odwołać do myśli Elliota Aronsona, który utrzymuje: „Gdy człowiek coś robi, to stara się [...] przekonać siebie (i innych), że jego postępowanie jest logiczne i rozsądne"13. Zasada ta wywodzi się

10 Cytaty oraz ich parafrazy pochodzą z następujących wierszy Grzegorza Wróblewskiego: (Rozczarowanie), Komuś na tym zależało, Bio i metal, Ikoniczna postać.

11 Wiersz pochodzi ze zbioru Kosmonauci wydanego w 2015, zamieszczony również w wyborze Pani Sześć Gier z 2019 roku.

W 2019 roku nakładem warszawskiego wydawnictwa Convivo ukazały się dwie książki poetyckie Grzegorza Wróblewskiego: Pani Sześć Gier oraz Runy lunarne.

13 E. Aronson Człowiek istota społeczna, przeł. J. Radzicki, Wydawnictwo Naukowe PWN, Warszawa 1997, s. 218. 
bezpośrednio z teorii ludzkiego poznania stworzonej przez Leona Festingera, zwanej teorią dysonansu poznawczego, definiowanego jako stan napięcia pojawiający się wówczas, gdy dana osoba ma jednocześnie dwa elementy poznawcze (idee, postawy, przekonania lub opinie), które są psychologicznie niezgodne ze sobą. Oczywiste jest, że współistnienie dwóch wykluczających się wzajemnie elementów poznawczych wymaga, mówiąc oględnie, podjęcia pewnych kroków eliminujących występujące sprzeczności. Uznanie bowiem współistnienia przeciwstawnych przekonań byłoby igraniem z bezsensem. Dlatego, jak dowodzi Aronson, człowiek jest motywowany do uzasadniania swego zachowania, gdy jest ono niezgodne z istniejącą już postawą ${ }^{14}$. Oznacza to, że podając powody podejmowania określonych decyzji, przekonujemy siebie oraz innych o logiczności i wadze swoich działań. Podobne rozumowanie odnajdziemy w postawie bohatera wiersza Metamorfoza, który uzasadnia wzrastające w nim poddanie wobec przypadkowo spotkanego zwierzęcia, odwołując się do poczucia odpowiedzialności za najbliższych. Z czasem troska ta, kosztem rodziny bohatera wiersza, zostaje przeniesiona na przypadkowo napotkane zwierzę.

W tym miejscu warto jednak zaznaczyć, że obu postaci wiersza nie należy rozpatrywać dosłownie, chodzi raczej o kontakt między dwoma osobnikami, w którego trakcie jeden z nich stara się zdominować drugiego. To zdarzenie stanowi kanwę wiersza. Świadczy o tym pewna ironia sytuacji, figura stylistyczna, która sugeruje wartościowanie opisanego zdarzenia (może nawet tytułowej Metamorfozy). Podczas lektury tego wiersza należy rozważyć rodzaj budowanych relacji oraz zasadę, jakiej to działanie podlega. Ale po kolei.

Chronologia zdarzeń w wierszu została podporządkowana kolejnym działaniom podmiotu, będącym odpowiedzią na stawiane przed nim żądania. To właśnie czynność (tj. działanie podjęte w celu nawiązania kontaktu werbalnego) otwiera utwór i w nim dominuje. Wszystkie żądania gołębia poznajemy z perspektywy procesów myślowych bohatera wiersza, co pozwala na dokładne przyjrzenie się motywacji wykonywanych przez niego czynności. Ukazanie naszkicowanej z tej perspektywy sytuacji zostało wzmocnione przez zwroty o silnym ładunku emocjonalnym. W wierszu nie ma niczego, co mogłoby zakłócić (bądź ograniczyć) dynamikę akcji. Co więcej, brak wielkich liter czy znaków interpunkcyjnych powodują zintensyfikowanie, przyspieszenie zdarzeń oraz wzrost napięcia. Wyizolowanie w tekście działań prowadzi do ich nasilenia oraz dodatkowo eliminuje wszystkie elementy, które

Zob. tamże, s. 220-221. 
mogłyby skierować uwagę czytelnika na sprawy mniej istotne dla wiersza. Poeta świadomie ogranicza ogląd do pokazania jedynie zarysu zdarzenia, by wyeksponować mechanizm doprowadzający do podziału ról. Postępowanie bohatera lirycznego jest z pozoru racjonalne - zgodnie z obowiązującymi normami odpowiada on na prośbę o udzielenie pomocy. Choć właśnie to dążenie do postępowania słusznie, dostosowanie do obowiązujących prawideł sprawiają, że spada u niego zdolność obiektywnej oceny rozgrywającej się sytuacji. Coraz bardziej angażuje się on w wyznaczane mu zadania, w wyniku czego niepostrzeżenie zostaje wmanewrowany w spełnianie kolejnych, bardziej wyrachowanych oczekiwań, by finalnie „awansować” na oddanego sługę.

Dla lepszego zrozumienia pokazanego tu schematu należy ponownie przywołać kontekst psychologii społecznej, a dokładniej wspomnianego już przeze mnie dysonansu poznawczego. Teoria Aronsona przedstawia bowiem człowieka nie "jako istotę racjonalną, lecz raczej jako istotę skłonną do racjonalizacji. Zgodnie z podstawowymi założeniami tej teorii, człowiek jest motywowany nie tyle do tego, by mieć słuszność, ile do tego, by wierzyć, że ma słuszność"15. Nic w sytuacji wiersza się nie zmieniło, nie został dodany żaden rekwizyt, a mimo to dokonał się znaczący zwrot. Tym, co uległo zasygnalizowanej w tytule utworu metamorfozie, jest relacja między dwoma postaciami. W wierszu poeta uwidacznia opisany przez psychologów mechanizm kierujący myśleniem i w konsekwencji działaniem człowieka. Bohater poetycki redukuje dysonans poznawczy, tj. przekonuje sam siebie o słuszności swych poczynań, podając powody, dla których spełnia kolejne żądania ( $(\ldots .$. ostatecznie rodzinę mam dużą, [...] w końcu mam rodzinę") i tak bardzo od nich się uzależnia, że stają się one motorem wszelkich jego działań, co w konsekwencji prowadzi do zachowania irracjonalnego.

Spotkanie wydaje się jedną z częstszych sytuacji, niemal znamiennych dla twórczości Grzegorza Wróblewskiego. Ma ono zazwyczaj w jego poezji charakter konfrontacyjny, naznaczony przemocą. Bohater wiersza jest niezwykle wyczulony na sygnały i bodźce z otoczenia, co w żaden sposób nie koliduje z zachowaniem przez niego asekuracyjności, nieufności oraz ostrożności wobec zdarzeń i sytuacji, z którymi ma się zmierzyć. W ujęciu Slavoja Žižka najczęstszym sposobem utrzymania dystansu wobec natarczywej bliskości nieludzkiego Bliźniego jest grzecznośćc ${ }^{16}$ rozumiana jako postępowanie

15 Tamże, s. 224.

16 Zob. S. Žižek, E.L. Santner, R. Kenneth Bliźni, przeł. E. Ulińska, Wydawnictwo Naukowe PWN, Warszawa 2013. 
według przyjętych norm, które stanowią asekuracyjne rozwiązania potencjalnych sytuacji konfliktowych lub zagrożeń.

Wróblewski, ilustrując w Metamorfozie spotkanie dwóch osobników, używa kreacji zwierzęcej do pokazania pewnego wzoru zachowania, choć nie odwołuje się przy tym do utrwalonego w literaturze, wielowiekowego zwierzęcego glosariusza. Wydaje się, że wychodzi on „poza imperium znaku, ku neoliteralnej relacji ze zwierzętami, anomaliami i nieorganicznymi innymi"17. Zwierzęta w jego twórczości poetyckiej są często traktowane dosłownie, jako inne obecności, które podobnie jak człowiek znajdują się pośród otaczających je systemów kodowania. Można przypuszczać, że Wróblewski takim sposobem wykorzystywania zwierząt jako motywu w utworze poetyckim zmienia również perspektywę oglądu rzeczywistości. Eksponuje pewne przesunięcia obecne w opisie czy rozumieniu rzeczywistości pozaliterackiej.

To przesunięcie można dostrzec także w sposobie kreowania figury bohatera tych wierszy.Z jednej strony jest on zdystansowany wobec zdarzeń, w których uczestniczy. Ta asekuracyjna postawa była, szczególnie w odniesieniu do wczesnej twórczości poetyckiej autora Ciamkowatościżycia, interpretowana w latach 8o. jako bunt i taka też retoryka wobec tej poezji zdominowała wtedy jej recepcję. Kategorię tę odnoszono zarówno do postawy poety, kontekstów w jego twórczości, jak i do konstrukcji bohatera. Akcentowano różne aspekty jego izolacji (m.in. psychiczną, mentalną, geograficzną) ${ }^{18}$. Z drugiej jednak strony pokazane $\mathrm{w}$ wierszach Wróblewskiego relacje człowiek-zwierzę są zazwyczaj oparte na współistnieniu czy współuczestniczeniu obu postaci w zdarzeniach. Daleka jestem od generalizowania czy ujednolicania sposobu wykorzystywania przez poetę tego motywu, jednoznaczne rozstrzygnięcie nie jest też łatwe, ale wydaje mi się, że rodzaj konfrontacji bohatera poetyckiego

17 R. Braidotti Zwierzęta, anomalie i nieorganiczni inni.

18 Zob. m.in. M. Stala Niedziela wZOO, „Tygodnik Powszechny 1993 nr 37; S. Pastuszewski Śmiertelne zapasy, "Akant" 2000 nr 10; M. Kwiatkowska Nie tylko w państwie duńskim może dziać się źle, "Portret” 2001 nr 12; G. Tomicki, /ak w Wilanowie, „Fa-art” 2001 nr 3. Pozostając w optyce tego zagadnienia, możliwe jest odszukanie jego objaśnienia w postmodernistycznej myśli Zygmunta Baumana, który pokazuje pewien dualizm charakterologiczny człowieka: „ludzie tęsknią za byciem częścią całości, jednocześnie pragnąć indywidualizacji (oryginalności). Jest to marzenie o przynależności przy jednoczesnym marzeniu o asertywności, potrzebie społecznego oparcia iżądzy autonomii, nagłej chęci do naśladowania i dążeniu do odrębności, lęku przed wyróżnianiem się i przerażeniu przed rozpadem własnego Ja" (zob. Z. Bauman Między chwilq a pięknem. O sztuce w rozpędzonym świecie, red. A. Zeidler-Janiszewska, M. Wójcik, Officyna, Łódź 2010, s. 56). Bohater wierszy Wróblewskiego wydaje się zamieszkiwać pośród tych dychotomicznych przestrzeni i rozpoznawać każdą z nich. 
z otoczeniem jest w pewnej mierze kolejnym - oprócz budowania strategicznych opowieści - przykładem kwestionowania antropocentrycznego jako jedynego oglądu (czy odniesienia do) rzeczywistości pozaliterackiej.

W wierszu Sroka w godzinach szczytu ${ }^{19}$ bohater rejestruje werystyczne obserwacje. Sam jednak sytuuje się na ich obrzeżach, nie wchodzi w żadne relacje - pozostaje bezstronnym, choć jednocześnie uważnym obserwatorem, dostrzegającym wpisane w krajobraz widzianego otoczenia niuanse. Tworzy rejestr zapisów codzienności służący do zbudowania obrazka, który w warstwie semantycznej zawiera odesłania do dyskursów pozornie odległych od literatury. Obraz „przemęczonych urzędników”, „smętny pochód ubezwłasnowolnienia" sugeruje odniesienia socjologiczne. Konstrukcja pierwszej strofy została oparta na zapisie szablonowych sposobów postrzegania. Obserwowany człowiek nie ma indywidualnych, jednostkowych cech, żyje i działa w zorganizowanym systemie, ,jest zrobiony przez społeczność. To oni kształtują w istocie tę indywidualną tożsamość, którą człowiek gotów się pysznić"20. Przytoczony cytat odnosi się co prawda do sposobu użycia stereotypu w twórczości Sławomira Mrożka, ale moim zdaniem istnieją pewne zbieżności w odniesieniu do zastosowania takiego opisu również wobec omawianego utworu Grzegorza Wróblewskiego. By wyjaśnić to zestawienie, trzeba kolejne elementy konstrukcyjne wiersza poddać dokładnej analizie. Urzędnicy to figura stylistyczna, która pełni w tekście funkcję synekdochy. Urzędnikiem jest każdy, kto, mówiąc kolokwialnie, związał swoje życie ze społecznie zorganizowanym systemem, w znacznym stopniu je regulującym. Krawaty to symbol ubezwłasnowolnienia, bez względu na to, czy odniesiemy ten rekwizyt do polityki przedsiębiorstw, które narzucają pracownikom styl ubioru, czy też skierujemy interpretację w stronę odniesień literackich, np. ku jednostce zdominowanej przez anonimową, nadrzędną instancję w świecie kreowanym w literaturze Franza Kafki ${ }^{21}$. Wszystkie wymienione rekwizyty tej strofy w jakimś sensie budują pojedynczy kadr opatrzony negatywnym (choć oszczędnym) komentarzem.

G. Wróblewski Pomieszczenia i ogrody, BN i Duński Instytut Kultury, Warszawa 2005, s. 9.

J. Błoński Mrożek i stereotypy, w: Narody i stereotypy, red. T. Walas, Międzynarodowe Centrum Kultury, Kraków 1995, s. 31.

O odniesieniach w twórczości Grzegorza Wróblewskiego do pisarstwa Franza Kafki czy Samuela Becketta pisali m.in. Lars Bukdahl czy Niels Henrik Svarre Nielsen, zob. http://www.wforma.eu/41, nowa-kolonia.html (13.05.2017). 
Kolejna strofa przeciwstawia światu ludzkiemu przyrodę, a dokładniej reguły oraz możliwości, jakie oferują swoim mieszkańcom oba te obszary. Figurą, nad którą warto zatrzymać uwagę nieco dłużej, jest tytułowa sroka. Barwa upierzenia tego ptaka w pewien sposób nawiązuje do stylu preferowanego w przedsiębiorstwach czy instytucjach. Podobnie jak w poprzednio omawianym wierszu, zwierzę jest pretekstem do eksponowania problematyki tekstu. Poeta w kolejnych strofach zestawia (może nawet przeciwstawia) pracownika urzędu oraz ptaka. Obie figury prezentują krańcowo różne propozycje relacji z otaczającym światem, dwa sposoby organizacji przestrzeni, rejestrując w ten sposób istnienie odmiennych możliwości uporządkowania najbliższego otoczenia. Wskazują na istnienie wielu hierarchii obowiązujących wśród wspólnot skupiających osobników o tożsamym doświadczeniu, jednocześnie demaskując struktury społeczne jako z jednej strony regulujące życie ich członków, z drugiej zaś pozbawiające ich indywidualności. Świadomość istnienia alternatywnego (nawet jeśli niedostępnego człowiekowi) obszaru jest dla bohatera wiersza krzepiąca.

Siedząca obok mnie sroka (zawsze wrażenie czyjejś opieki!), może w każdej chwili rozprostować skrzydła i odlecieć w fantazyjne Morza Deszczów.

\section{Dziwne,}

lecz w pewnym sensie, wersja ta podnosi mnie na duchu.

Psy, koty, muchy, pająki, gołębie, wrony, kałamarnice - czytelnik podczas lektury książek poetyckich Grzegorza Wróblewskiego spotyka zaskakująco wielu różnorodnych przedstawicieli fauny. Jednocześnie przyjmowana za oczywistą hierarchia gatunkowa, która stawia na szczycie drabiny ewolucyjnej człowieka, zostaje, jak już wspomniałam, w tych wierszach poważnie naruszona. Śledząc motyw zwierząt oraz szczególny charakter relacji człowiek-zwierzę w utworach Wróblewskiego, można odkryć, że poeta używa kreacji zwierzęcych w znaczeniu niemal dosłownym, choć jest w tej strategii pewna dychotomia.

$\mathrm{Z}$ jednej strony w jego poezji jest utrwalone to, co widzi bohater tych wierszy. To niemal mechanicznie zarejestrowane obrazy. $Z$ drugiej jednak są one równocześnie pewnego rodzaju projekcją zdarzenia lub sytuacji, widzeniem niejako od środka. Ta podwójna perspektywa wydaje się możliwa dzięki, po pierwsze, umieszczeniu bohatera (a więc i punktu obserwacyjnego) 
na obrzeżach ludzkiego świata, tak by w jego polu widzenia znajdowały się zarówno fizyczność postaci (również zwierzęcych), jak i możliwość objęcia tej ich - osadzonej w czasie i przestrzeni - fizyczności refleksją. Po drugie zaś, dzięki połączeniu obu tych z pozoru wykluczających się sposobów obserwacji za pośrednictwem języka, pochodzącego ze świata i ten świat kształtującego.

\section{Abstract}

\section{Justyna Kasperek}

JAN KOCHANOWSKI UNIVERSITY OF KIELCE

On the Edge of the Human World: Animals in Grzegorz Wróblewski's Poems

Examining Grzegorz Wróblewski's poems Kasperek focuses on animal creations, which possess their own coding systems and can therefore be read in relation to post-humanism. By placing the poems' protagonist (and point of view) on the margins of the human world, Wróblewski produces works of a twofold perspective, which allows the poems to convey both the physicality of the animals as the possibility of reflecting on their physicality, situated as it is in time, space and language.

\section{Keywords}

Grzegorz Wróblewski, poetry, animal creations, post-humanism 